\title{
MENINGKATKAN AKTIVITAS SISWA MELALUI MODEL PEMBELAJARAN NHT PADA MATERI LINGKARAN DI KELAS VIII SMP NEGERI 3 KUBU TAHUN 2016
}

\author{
Cahye \\ SMP Negeri 3 Kubu, Kubu Raya, Kalimantan Barat \\ E-mail: cahye3@gmail.com
}

\begin{abstract}
This research is motivated by the low activity of students in receiving lessons in the classroom. This classroom action research aims to improve mathematics learning activities in class VIII SMP Negeri $3 \mathrm{Kubu}$. The solution to low activity of students conducted by researchers through the Numbered Heads Together (NHT) of cooperative learning model. The research was conducted in three cycles to 32 students. The technique of data collecting is observation by teachers and collaborators. Student activity expressed by categories of high, medium or low, the success of NHT learning models is successful, less successful or unsuccessful. Activity criteria determined by the researchers themselves with $60 \%$ of students are actively involved. Activity in this research there are four, namely: 1). Visual activities, 60\% 2). Oral activities, 90\%, 3). Motor activities, 85\%, 4). Writing activities, $100 \%$. Thus the NHT learning models successfully increased student activity.
\end{abstract}

Keywords: Numbered Heads Together, student activity, circle

Karakteristik pembelajaran matematika lebih menekankan pada membangun pengetahuan tentang konsep yang sedang dibahas. Proses membangun pengetahuan memerlukan kreativitas guru di dalam mengajar. Kreativitas yang di miliki guru di dalam mengajar akan menciptakan apa yang dinamakan dengan "PAIKEM-GEMBROT". Atau disebut juga dengan pembelajaran aktif, inovatif, kreatif, menyenangkan, gembira dan berbobot, sehingga siswa ikut aktif dalam pembelajaran dan pada akhirnya siswa memiliki pengalaman belajar yang bermakna dan menyenangkan. Sedang guru yang mengajar di dalam kelas hanya berperan sebagai fasilitator dan motivator. Dari peneliti itu sendiri adalah karena ada rasa senangnya di dalam mengajar untuk menggunakan metode yang bervariasi untuk menciptakan suasana mengajar yang menyenangkan. Karena peneliti tahu pelajaran matematika itu memang jarang disukai siswa walaupun memang ada siswa-siswa tertentu yang mau belajar matematika. 
Berdasarkan fakta di lapangan peneliti peroleh data bahwa: 1) Hasil belajar di dalam kelas dilihat dari hasil ulangan semester 1 biasa-biasa saja tidak ada kenaikan yang signifikan. 2) Dalam kegiatan belajar mengajar, guru di dalam memberikan materi lebih banyak menggunakan metode ceramah dan tanya jawab saja. Sebagian besar siswa kurang aktif seperti tidak memperhatikan penjelasan guru, mengobrol dengan teman, tidak percaya diri dalam menjawab pertanyaan dan sering keluar kelas pergi ke wc berbarengan. 3) Guru jarang menggunakan papan tulis sebagai media saat mengajar, padahal ini adalah cara guru untuk memberi contoh kepada siswa agar siswa juga suka menulis pada akhirnya. 4) Siswa jarang mengajukan pertanyaan walaupun pelajaran tersebut kurang jelas, akibatnya pada saat guru memberikan pertanyaan, sedikit sekali siswa yang bisa menjawabnya dengan benar. 5) takut untuk bertanya, tidak menjawab kalau ditanya, tidak diberdayakannya siswa pandai, tidak menulis jika tidak disuruh, tidak membaca jika tidak disuruh membaca. Bahkan ada siswa yang merasa kesulitan dalam memahami suatu pelajaran tetapi mereka segan bahkan takut untuk bertanya pada guru.

Aktivitas siswa di dalam berlangsungnya pembelajaran masih rendah, karena tidak diberdayakannya siswa pandai. Hal ini dipertegas oleh Ekasari (2009) yang menyatakan bahwa pembelajaran model konvensional yang sering ditetapkan guru mengakibatkan siswa enggan dan jenuh dalam menerima pelajaran, sehingga tujuan yang ditetapkan guru tidak tercapai secara optimal yang menyebabkan prestasi belajar siswa rendah. Seolah-olah pelajaran saat itu hanya untuk siswa tertentu saja. Dan siswa yang lain hanya duduk manis sebagai pendengar dan kalau guru bertanya tentang materi yang baru saja ditampilkan siswa bahkan tak mau menjawab karena takut jawabannya salah.

Dari kegiatan pembelajaran diatas, bahwa kegiatan pembelajaran yang dilakukan oleh guru belum menggambarkan karakteristik membangun pengetahuan sehingga siswa terlihat jenuh karena kurang diperhatikan, Mereka diperlakukan sebagai obyek yang harus duduk manis memperhatikan guru yang sedang menerangkan. Selain itu pembelajaran yang berlangsung seolah-olah hanya untuk sekelompok siswa tertentu. Ini berarti pembelajaran di kelas terasa sangat membosankan yang dirasakan oleh siswa yang memang betul-betul tidak mau atau tidak menyenangi pelajaran tersebut. Tapi lain hal nya dengan siswa yang mempunyai rasa ingin tahu tentang pembelajaran yang dipelajari, siswa tersebut tetap konsen dengan apa yang mereka lihat dan dengar dari gurunya serta mau bertanya tanpa harus di suruh dan mau menjawab kalau di tanya, serta mau ke depan kelas untuk mempresentasikan hasil kerjanya. Siswa tersebut mau menulis hal-hal yang penting walaupun harus tanpa disuruh oleh guru yang mengajar saat itu.

Dalam belajar siswa agak jarang menulis hal-hal yang penting ke dalam bukunya, ini karena gurunya saat menjelaskan materi di depan kelas juga tidak menulis di papan tulis, sehingga papan tulis 
bersih. Apa yang dilakukan guru saat mengajar cenderung siswa pasti mengambil contoh dari apa yang kita lakukan. Memperhatikan kondisi di atas perlu suatu perbaikan yang dapat memanfaatkan siswa dalam proses kegiatan belajar mengajar di dalam kelas.

Berdasarkan latar belakang dari uraian data tersebut di atas sangat menarik perhatian peneliti untuk melakukan penelitian tindakan kelas, untuk mengaktifkan siswa salah satu caranya adalah melalui model pembelajaran kepala bernomor struktur (Numbered Heads Together / NHT) pada materi lingkaran di kelas VIII semester 2 SMP Negeri 3 Kubu tahun 2016.

Secara umum tujuan dari penelitian ini adalah untuk memperbaiki proses pembelajaran matematika yang selama ini kurang diminati bahkan ditakuti oleh sebagian siswa sedangkan secara khusus tujuan penelitian ini dirumuskan sebagai berikut: 1) Untuk memperoleh informasi dan menganalisis proses kegiatan perencanaan setiap siklus dalam pembelajaran matematika di kelas VIII SMP Negeri 3 Kubu yang diajarkan melalui model NHT, pada materi lingkaran. 2) Untuk memperoleh informasi dan menganalisis proses kegiatan pelaksanaan setiap siklus dalam pembelajaran matematika di kelas VIII SMP Negeri 3 Kubu yang diajarkan melalui model NHT, pada materi lingkaran. 3) Untuk mengetahui aktivitas siswa dalam pembelajaran matematika di kelas VIII SMP Negeri $3 \mathrm{Kubu}$ yang diajarkan melalui model NHT. Muhammad Nur (2005) model pembelajaran kooperatif tipe NHT pada dasarnya merupakan sebuah variasi diskusi kelompok dengan ciri khasnya adalah guru hanya menunjuk seorang siswa yang mewakili kelompoknya tanpa memberi tahu terlebih dahulu siapa yang akan mewakili kelompoknya.

Number Heads Together adalah suatu pembelajaran yang lebih mengedepankan kepada aktivitas siswa dalam mencari, mengolah, dan melaporkan informasi dari berbagai sumber yang akhirnya dipresentasikan di depan kelas. NHT pertama kali diperkenalkan oleh Spencer Kagan (1992). Model NHT adalah bagian dari model pembelajaran kooperatif struktural, yang menekankan pada struktur-struktur yang dirancang untuk mempengaruhi pola interaksi siswa. Model pembelajaran NHT ini secara tidak langsung melatih siswa untuk saling berbagi informasi, mendengarkan dengan cermat serta berbicara dengan penuh perhitungan, sehingga siswa lebih produktif dalam pembelajaran. Tipe ini memberikan kesempatan siswa untuk saling membagikan ide-ide dan mempertimbangkan jawaban yang paling tepat. Selain itu tipe ini juga mendorong semangat siswa dalam meningkatkan aktivitas kerja siswa dan dapat dilaksanakan pada tingkatan usia anak.

Terkait dengan aktivitas siswa dalam pembelajaran, Trianto (2007) mengatakan bahwa guru tidak dibenarkan mengelola tingkah laku siswa dalam kelompok secara ketat, dan siswa memiliki ruang dan peluang untuk secara bebas mengendalikan aktivitas-aktivitas di dalam kelompoknya. Semakin banyak siswa yang melakukan aktivitas maka akan lebih kuat pemahaman siswa dalam suatu materi yang disampaikan 
peneliti. Silbermen, Melvin (2006) telah memodifikasi dan memperluas pernyataan Confusius menjadi apa yang ia sebut paham belajar aktif, yaitu: apa yang saya dengar saya lupa, apa yang saya dengar dan lihat saya ingat sedikit, apa yang saya dengar, lihat dan tanyakan atau didiskusikan dengan beberapa teman saya mulai paham, apa yang saya dengar, lihat, diskusikan dan lakukan, saya memperoleh pengetahuan dan ketrampilan, apa yang saya ajarkan kepada orang lain, saya menguasainya.

Dari pernyataan Silbermen Melvin inilah peneliti tertarik untuk meningkatkan aktivitas belajar siswa di SMP Negeri 3 Kubu semester 2 tahun 2016.

\section{METODE}

Bentuk penelitian ini adalah penelitian tindakan kelas (classroom action research). Menurut Mulyasa (2010), Penelitian Tindakan Kelas (PTK) adalah penelitian tindakan yang dilakukan dengan tujuan untuk memperbaiki kualitas proses dan hasil belajar sekelompok siswa. Mengacu dari uraian yang disampaikan oleh Arikunto (2006) yang menjadi obyek tindakan dalam penelitian ini terdiri dari beberapa unsur, yaitu unsur siswa, unsur guru dan unsur materi (RPP).

Metode pembelajaran yang digunakan dalam penelitian adalah model NHT. Model ini adalah bagian dari model pembelajaran kooperatif struktural, yang menekankan pada struktur-struktur yang dirancang untuk mempengaruhi pola interaksi siswa agar bekerja saling bergantung pada kelompok-kelompok kecil secara kooperatif. Model ini dapat dijadikan alternatif variasi model pembelajaran sebelumnya. Di bentuk kelompok heterogen, setiap kelompok memiliki satu nomor. guru mengajukan pertanyaan untuk didiskusikan dalam kelompok. Guru menunjuk salah satu nomor untuk mewakili kelompoknya. Sehingga cara ini menjamin keterlibatan total semua siswa. Cara ini upaya yang sangat baik untuk meningkatkan tanggung jawab individual di dalam diskusi kelompok.

Penelitian tindakan kelas dilaksanakan di SMP Negeri 3 Kubu, Jl. Raya Pinang Dalam untuk mata pelajaran matematika. Penelitian dilakukan selama 2 bulan, yaitu mulai bulan Januari berakhir sampai bulan Maret 2016. Penentuan waktu penelitian mengacu pada kalender akademik sekolah, karena PTK memerlukan beberapa siklus yang membutuhkan proses belajar mengajar yang efektif di kelas. Sedangkan subyek penelitian adalah siswa SMP Negeri 3 Kubu kelas VIII dengan jumlah siswa sebanyak 32 orang, terdiri dari 14 laki-laki dan 18 siswa perempuan. Pemilihan kelas VIII bertujuan untuk memperbaiki dan meningkatkan keaktifan siswa dalam pembelajaran matematika di kelas VIII materi lingkaran.

Alat pengumpul data yang digunakan dalam penelitian terdiridari lembar Observasi, untuk pengamatan (pengambilan data) mencatat seberapa jauh efek tindakan yang telah mencapai sasaran. Dalam hal ini lembar observasi yang digunakan adalah: a) Untuk mengetahui pelaksanan kegiatan peneliti mengajar dengan menggunakan RPP melalui model NHT. b) Untuk mengetahui aktivitas kegiatan siswa saat proses pembelajaran melalui model NHT. 
Untuk mengukur keberhasilan tiap siklus dapat dilihat dari indikator sebagai berikut: a) Kesesuaian pelaksanaan tindakan (pembelajaran) dengan RPP. b) Persentase keaktifan siswa selama KBM yang ditentukan oleh peneliti dari hasil kesepakatan dengan kolaborator/ observer sekurang-kurangnya $\geq 60 \%$ dengan kategori cukup aktif.

Hakekat belajar matematika didasarkan pada pandangan konstruktivisme, yakni belajar matematika dihadapkan pada masalah tertentu berdasarkan pengetahuan yang diperolehnya ketika belajar dan berusaha memecahkannya (Hamzah B.Uno, 2007).

Prosedur yang digunakan dalam penelitian meliputi empat tahapan yaitu tahap perencanaan, pelaksanaan, pengamatan dan refleksi. kegiatan perencanaan mencakup: (1) identifikasi masalah, (2) analisis penyebab adanya masalah, dan (3) pemecahan masalah. Berikut ini adalah deskripsi kegiatan PTK:

Tahap Perencanaan.

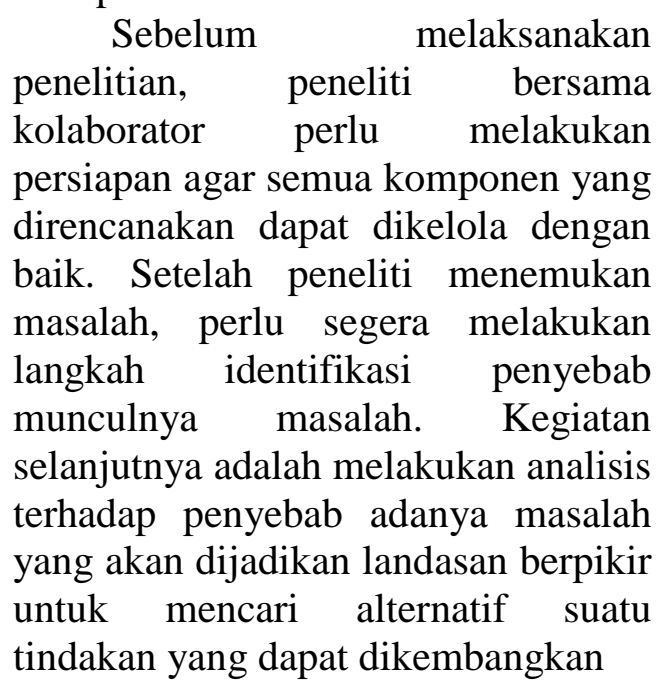

sebagai bentuk solusi atau pemecahan masalah. Kegiatan pada tahap ini, peneliti merencanakan: 1) Membuat rencana pelaksanaan pembelajaran (RPP) dengan materi lingkaran yaitu menyebutkan unsur-unsur lingkaran, menghitung keliling lingkaran, dan menghitung luas lingkaran. 2) Membuat soal evaluasi siklus 3) Membuat lembar observasi untuk siswa dan peneliti. 4)Menunjuk salah satu observer dari teman sejawat untuk mengamati berlangsungnya penelitian/ tindakan. 5) Menggunakan media pembelajaran terutama buku paket, serta benda yang berbentuk lingkaran. 6) Melakukan validasi instrumen penelitian. 7) Menentukan waktu atau jadwal pelaksanaan PTK.

Tahap pelaksanaan tindakan.

Kegiatan yang dilaksanakan pada tahap pelaksanaan tindakan adalah melaksanakan pembelajaran yang tertuang dalam RPP. Pelaksanaan dilakukan dalam 3 siklus, masing-masing siklus terdiri dari 2 kali pertemuan.

Tahap Refleksi. Peneliti melakukan refleksi berdasarkan pelaksanaan pembelajaran dan hasil pengamatan pada siklus kedua, kemudian menganalisis dan membuat kesimpulan.

Penelitian tindakan kelas dilaksanakan dalam bentuk siklus berulang-ulang mencakup empat langkah yaitu: perencanaan, pelaksanaan, pengamatan, dan refleksi. Secara ringkas rancangan alur yang digunakan dalam PTK ini dapat dilihat melalui gambar 1: 


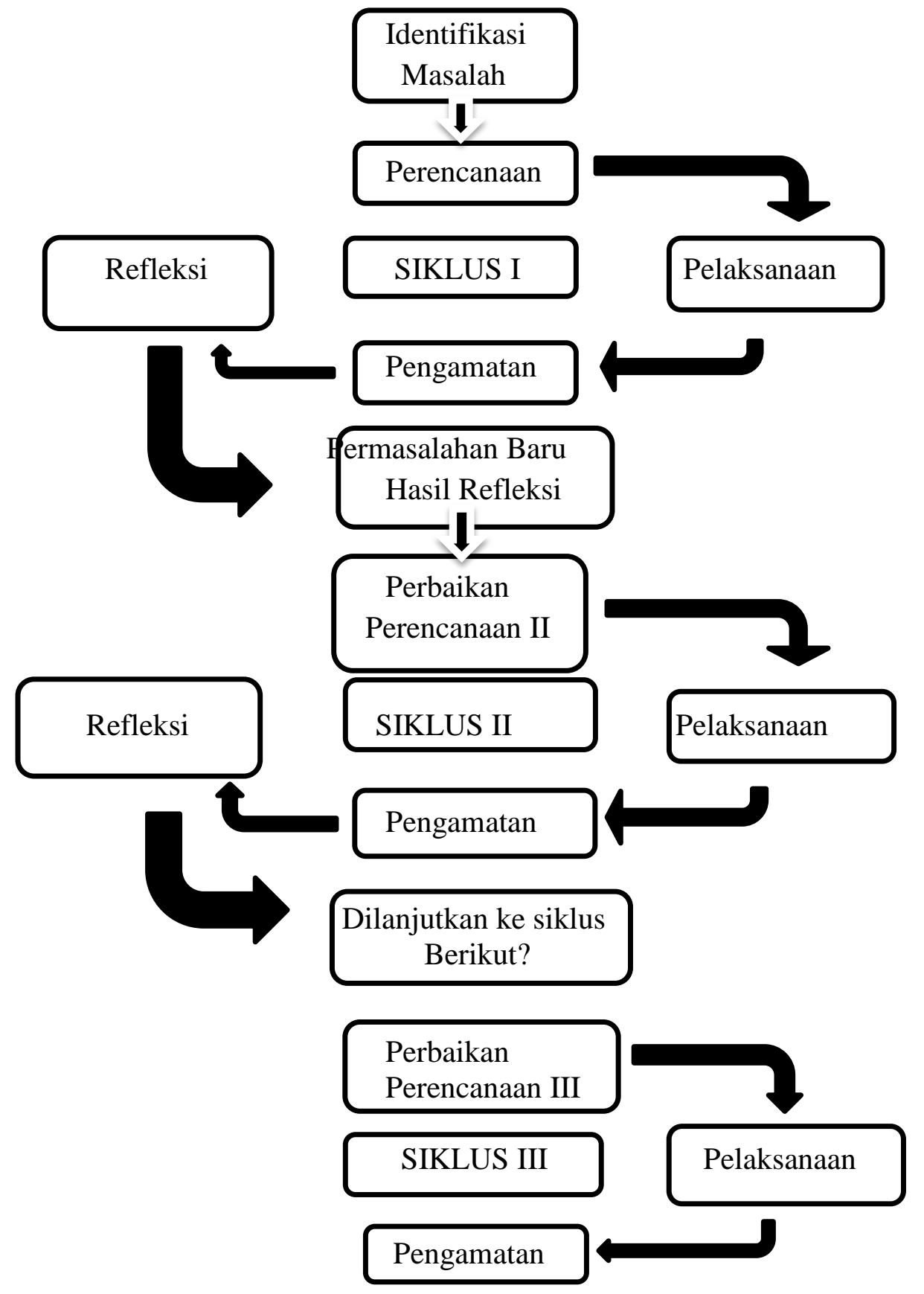

Gambar 1.Model Siklus Penelitian Tindakan Kelas (PTK)

\section{HASIL DAN PEMBAHASAN}

Aktivitas belajar siswa yang tampak di kelas selama proses pembelajaran berlangsung diamati menggunakan lembar observasi disertai catatan lapangan. Observasi terhadap aktivitas belajar siswa dilakukan oleh observer dari guru IPS yang telah ditunjuk oleh kepala 
sekolah. Berdasarkan hasil penelitian yang telah dilaksanakan, aktivitas siswa dari siklus I, siklus II, dan siklus III dapat peneliti tampilkan dari hasil pengamatan observer pada (tabel 1) berikut ini:

Tabel 1. Data hasil observasi aktivitas siswa siklus I, siklus II dan siklus III

\begin{tabular}{|c|c|c|c|c|c|c|c|c|c|c|c|c|}
\hline \multirow{2}{*}{ No } & \multirow[b]{2}{*}{$\frac{\mathscr{Q}}{\frac{N}{5}}$} & \multicolumn{11}{|c|}{ Nama Indikator Yang disajikan } \\
\hline & & 1 & 2 & 3 & 4 & 5 & 6 & 7 & 8 & 9 & 10 & \\
\hline & & 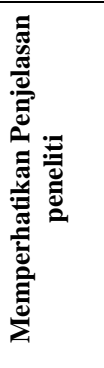 & 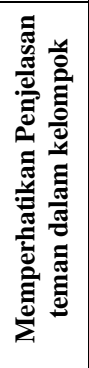 & 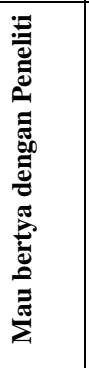 & 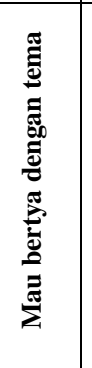 & 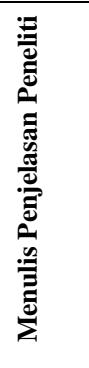 & 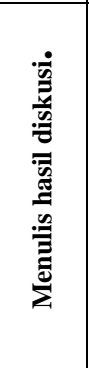 & 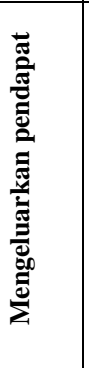 & 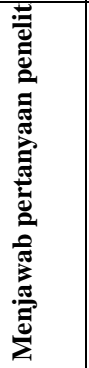 & 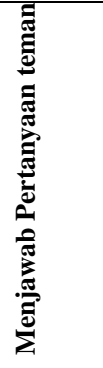 & 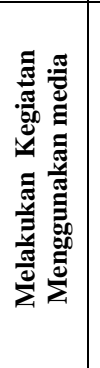 & 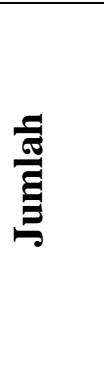 \\
\hline 1 & I & 75 & 75 & 37,5 & 25 & 50 & 37,5 & 50 & 62,5 & 25 & 37,5 & 452 \\
\hline 2 & II & 87,5 & 75 & 50 & 50 & 50 & 68,8 & 65,6 & 50 & 34,4 & 75 & 606,3 \\
\hline 3 & III & 96,9 & 93,8 & 62,5 & 62,5 & 100 & 100 & 65,6 & 65,6 & 46,9 & 100 & 793,8 \\
\hline
\end{tabular}

Data tersebut diatas menunjukkan bahwa peningkatan aktivitas siswa dari siklus I ke siklus II sebesar $15,43 \%$ dan dari siklus II ke siklus III terjadi peningkatan sebesar $18,75 \%$. Dengan demikian rata-rata peningkatan aktivitas siswa dalam pembelajaran $17.09 \%$.

Siklus I aktivitas siswa yang terlihat oleh peneliti belum sepenuhnya dilakukan oleh semua siswa. Ini dikarenakan siswa masih ada yang ijin ke wc berbarengan, bergurau sama temannya, kebiasaan-

kebiasaan yang dilakukan siswa saat berlangsungnya kegiatan belajar mengajar seperti hari-hari sebelumnya masih kelihatan. Siswa belum mengubah banyak sifatnya dalam penelitian pertama yang peneliti lakukan, karena memang pada pertemuan pertama ini peneliti belum memberitahukan seperti apa model pembelajaran NHT. Pada pembentukan kelompok siswa sangat gaduh. Tapi yang banyak siswa adalah malas dan selalu menumpukkan suatu pekerjaan pada 
siswa yang dianggapnya lebih pandai untuk mengerjakan pekerjaan itu sedang siswa yang lain hanya menunggu saja.

Siklus II aktivitas siswa sudah mulai menunjukkan tingkat aktivitas kategori sedang. Ini dapat peneliti lihat dari hasil observasi yang dilakukan oleh observer dari lembar observasi siswa pada pertemuan pertama siklus II. Tingkat aktivitas siswa mengalami kenaikan secara perlahan tapi pasti dari sepuluh aspek yang peneliti tampilkan ini berkat dan kerja keras peneliti untuk memotivasi siswa agar penelitian yang peneliti lakukan ini bisa berhasil. Bagaimanapun juga suatu permasalahan pasti bisa diatasi asal adanya kerjasama yang baik.

Pada tabel di atas untuk siklus I dan siklus II dapat dilihat bahwa pada aspek menulis penjelasan peneliti, tingkat aktivitas siswa tidak mengalami kenaikan masih kategori biasa ini dikarenakan siswa sudah punya buku masing-masing dan

siswa belum mengerti arti pentingnya menulis agar ingatan kita lebih kuat lagi. Maka dari itu pada pertemuan selanjutnya peneliti menyarankan kepada seluruh siswa agar selalu mencatat tentang apa saja yang peneliti jelaskan agar siswa lebih banyak mengingat materi yang sudah dijelaskan walaupun semua itu ada dalam buku.

Siklus III aktivitas siswa mengalami kenaikan yang signifikan yang sangat membanggakan peneliti. Ini dapat peneliti lihat dari hasil observasi observer terhadap lembar observasi siswa saat belajar mengajar berlangsung. Hanya pada siklus III ini untuk aspek menjawab pertanyaan teman belum dikatakan tuntas tapi pada setiap siklus mengalami peningkatan saja. Maka dari itu observer dan peneliti memutuskan penelitian ini cukup sampai siklus III saja.

Siklus I, siklus II, dan siklus III untuk sepuluh aspek yang peneliti berikan semua mengalami peningkatan, hanya ada satu aspek dari sepuluh aspek yang diberikan yang tidak tuntas tapi tetap mengalami peningkatan. Semua ini karena kerja keras yang peneliti lakukan agar penelitian ini berhasil sesuai dengan tujuan KTSP. Menurut Kussavita (2007) aktivitas yang timbul dari siswa akan mengakibatkan terbentuknya pengetahuan dan ketrampilan yang akan mengarah pada peningkatan prestasi. Sejalan dengan itu, Isjoni (2007) menyatakan bahwa dalam pembelajaran kooperatif, siswa terlibat aktif pada proses pembelajaran sehingga memberikan dampak positif terhadap kwalitas interaksi dan komunikasi serta memotivasi siswa untuk meningkatkan prestasi belajarnya. Untuk menciptakan agar siswa aktif maka seorang guru harus kreatif.

Dari data yang diperoleh, peningkatan tingkat aktivitas siswa dalam proses pembelajaran dikelas VIII SMP Negeri 3 Kubu selama tiga siklus dalam penelitian tindakan kelas dapat lebih jelas terlihat pada diagram berikut di bawah ini: 
Diagram 1. Aktivitas Siswa Pada Siklus I, Siklus II, Siklus III

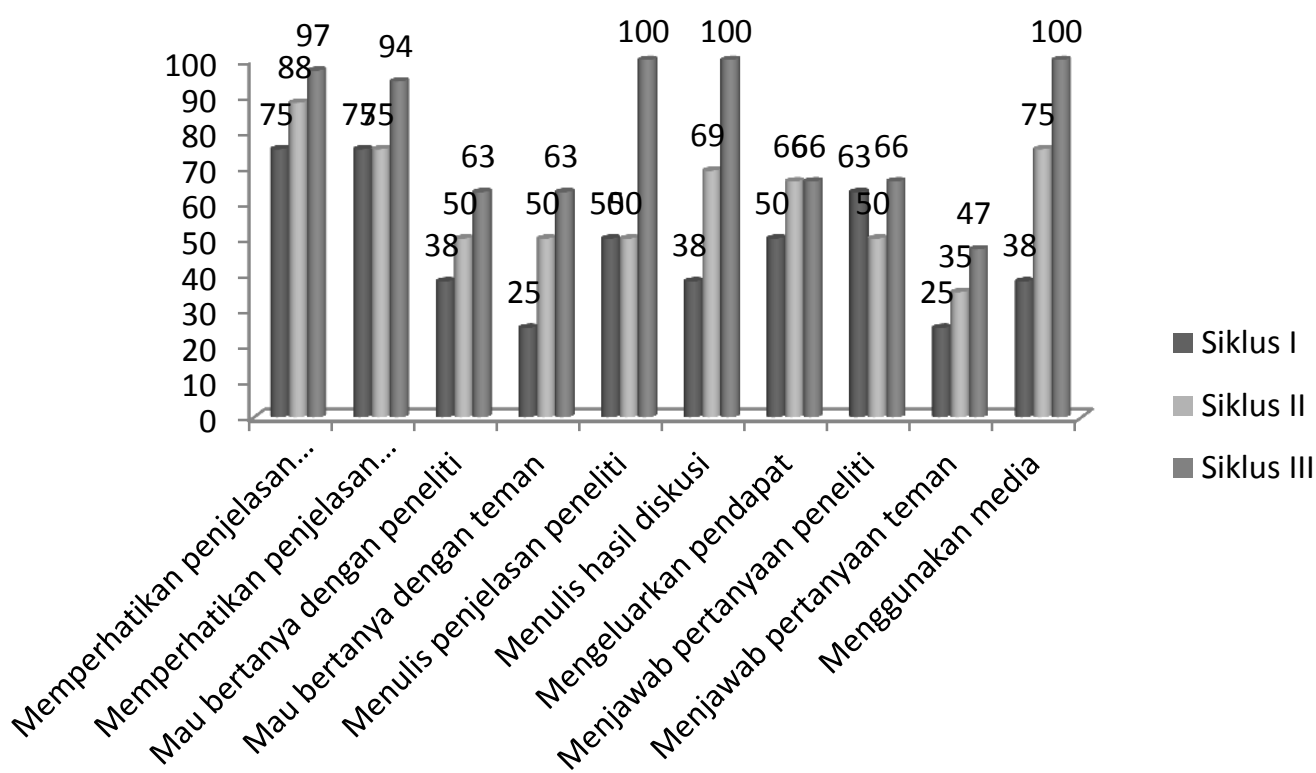

Dari diagram diatas dapat peneliti jelaskan bahwa aktivitas siswa siklus I, siklus II, dan siklus III mengalami peningkatan yang signifikan. Pada kegiatan awal dari setiap siklus observasi observer bersama peneliti adalah mempersiapkan rencana pelaksanaan pembelajaran (RPP), menyusun lembar observasi terhadap aktivitas belajar siswa, membuat lembar catatan lapangan untuk peneliti dan siswa, menyiapkan pembentukan kelompok siswa secara heterogen dengan beranggotakan 4 orang siswa serta observer dari teman sejawat untuk mengamati berlangsungnya tindakan. sedangkan lembar observasi peneliti dan aktivitas belajar siswa divalidasi oleh observer.

Siklus I aktivitas siswa memperhatikan penjelasan peneliti saat pembelajaran berlangsung sudah cukup baik. Hanya masih ada sebagian siswa yang memang kebiasaannya saat guru menjelaskan ada yang suka ngobrol bersama temannya, ada juga yang saat guru menjelaskan di depan kelas kesempatan pergi ke wc berbarengan, padahal nanti yang ke wc hanya satu orang yang lain ikut keluar saja. Pada siklus I ini siswa yang aktif memperhatikan penjelasan materi oleh peneliti dilihat dari lembar observasi observer dari 32 siswa yang ikut memperhatikan ada 24 siswa. Kebiasaan-kebiasaan yang terlihat pada siklus I ini memang tak ubahnya dengan pertemuan-pertemuan di kelas pada hari-hari biasa, sebelum dilaksanakannya penelitian.

Siklus II aktivitas siswa memperhatikan penjelasan peneliti saat pembelajaran berlangsung sudah cukup baik. Dilihat dari lembar observasi yang peneliti siapkan hanya mengalami peningkatan satu siswa saja. Pada refleksi siklus sebelumnya sudah disarankan agar siswa dalam proses belajar berusahalah untuk mencoba mengikuti proses 
pembelajaran sehingga nanti apa yang peneliti jelaskan di depan kelas tentang materi lingkaran dan unsurunsurnya betul-betul dapat di pahami. - Sesuai dengan yang diinginkan peneliti menurut teori yang dikemukakan oleh Silbermen Melvin yang bunyinya adalah apa yang ia sebut paham belajar aktif, yaitu: apa yang saya dengar saya lupa, apa yang saya dengar dan lihat saya ingat sedikit. Walaupun begitu masih mengalami peningkatan.

Dari hasil refleksi siklus II, pada siklus III aktivitas siswa memperhatikan penjelasan peneliti saat pembelajaran berlangsung sudah cukup baik. Usaha yang peneliti lakukan untuk mengajak siswa agar memperhatikan penjelasan materi yang peneliti sampaikan di depan kelas berhasil dengan baik. Dari 32 siswa yang hadir pada siklus III ini ada satu siswa yang observer lihat kurang memperhatikan peneliti yang sedang menjelaskan di depan. Walaupun siswa ini ada melihat ke depan tetapi pandangan siswa ini tidak sungguh-sungguh tertuju ke depan dan paham apa yang telah disampaikan peneliti. Ini dibuktikan dengan apa yang baru peneliti jelaskan tadi ditanyakan lagi pada siswa ini dan tidak bisa jawab. Dan untuk selanjutnya pertanyaan itu peneliti berikan pada siswa yang memperhatikan ternyata bisa dijawab dengan baik.

Aktivitas siswa memperhatikan penjelasan teman dalam kelompok sangat bagus ini dapat peneliti lihat tatkala siswa-siswi saling berkomunikasi dalam menyelesaikan tugas kelompok. Mereka saling mendengar dan bekerja apa yang disarankan satu sama lain.
Pada salah satu kelompok yang lain tidak seperti yang peneliti harapkan mereka malah bergurau sedang siswa yang lain dari kelompok itu bekerja sendiri. Dalam hal ini memang tidak ada penunjukan ketua kelompok. Karena pembelajaran model NHT adalah pembelajaran kerjasama dalam menyelesaikan soal dan untuk mempresentasikannya ditunjuklah salah satu nomor dan nomor yang sama pada kelompok yang lain bertanggungjawab terhadap jawabannya.

Siklus II aktivitas siswa memperhatikan penjelasan teman masih tetap tidak ada kenaikan. Kebiasaan menyerahkan pekerjaan di dalam kelompok memang sudah terjadi sejak sebelum dilaksanakan penelitian. Kebiasaan itu menular lagi, pada hal saat refleksi siklus I di sarankan agar dalam penelitian ini setiap kelompok untuk mengajak sesama teman kelompoknya ikut aktif dalam pembelajaran yang sedang berlangsung.

$\begin{array}{llr}\text { Setelah } & \text { dilakukan } & \text { refleksi, } \\ \text { siklus III aktivitas } & \text { siswa } \\ \text { memperhatikan } & \text { penjelasan } & \text { teman } \\ \text { mengalami peningkatan } & \text { yang }\end{array}$
signifikan. Dari 32 siswa yang mengikuti ada 30 siswa aktif dalam kelompoknya. Ini berarti bahwa suatu proses belajar mengajar bisa berjalan sesuai yang kita inginkan bahwa agar siswanya bisa aktif gurunya harus kreatif. Sesuailah apa yang di tuntut dalam KTSP.

Aktivitas siswa mau bertanya dengan peneliti tentang materi yang peneliti sampaikan pada siklus I baru mencapai 38\% atau baru 12 siswa saja dari 32 siswa yang hadir saat itu. Perasaan takut salah atau malu kalau ditertawakan teman masih terlihat 
dari wajah siswa itu sendiri. Untuk pertemuan berikutnya peneliti berupaya menyarankan agar siswa membuang jauh- jauh perasaan takut dalam belajar agar siswa berjiwa berani dalam belajar. Pada siklus II aktivitas siswa mau bertanya pada peneliti mengalami peningkatan. Begitu juga pada siklus III tetap mengalami peningkatan.

Aktivitas siswa mau bertanya atau melakukan komunikasi dalam kelompok saat kegiatan berlangsung mengalami peningkatan yang baik sekali. Ini dapat peneliti lihat dari kerja siswa dalam kelompok yang peneliti lakukan menggunakan model NHT. Rasa takut pada diri siswa dalam bertanya sesama teman lebih tipis di bandingkan dengan rasa takut bertanya dengan peneliti. Salah dalam bertanya dengan teman hanya dalam kelompok itu saja yang tahu. Tapi salah dalam bertanya dengan peneliti seluruh siswa yang hadir mengetahuinya. Itulah sebabnya siswa lebih mau bertanya dengan temannya sendiri walaupun jawaban yang diperoleh juga salah ketimbang dengan peneliti. Bagaimanapun juga siswa yang mau bertanya memang siswa yang sudah biasa memang mau bertanya. Untuk siswa yang memang pendiam dan tak menguasai materi pelajaran lebih baik diam saja. Dari diagram yang peneliti buat terlihat bahwa siswa yang mau bertanya tentang materi pelajaran dari siklus I ke siklus II sampai siklus III masih tetap mengalami peningkatan.

Aktivitas siswa mau menulis penjelasan peneliti tentang materi pembelajaran pada siklus I dan siklus II hanya 50\% saja. Ini dapat peneliti lihat dari hasil observasi observer dari lembar observasi. Ini dimungkinkan karena siswa sudah punya buku jadi tak perlu mencatat lagi di dalam buku catatan. Kemungkinan kedua siswa memang malas mencatat kalau tak disuruh mencatat. Sehingga kalau peneliti bertanya kembali kepada salah seorang siswa yang memang hanya mempunyai kemampuan berpikir kurang, siswa tersebut tak bisa menjawab dan kalau disuruh buka catatan dari yang sudah didengar dan apa yang dicatatnya itu tidak ada catatannya sehingga siswa tinggal diam saja. Oleh sebab itu pada siklus pertemuan berikutnya yaitu siklus III peneliti menyarankan betul agar setiap siswa dalam belajar mengikuti pelajaran harus mencatat walaupun pada buku masing-masing sudah ada. Ini sesuai dengan teori yang di kemukakan oleh Silbermen, Melvin yaitu apa yang saya dengar saya lupa, apa yang saya lihat dan saya dengar saya ingat sedikit dan apa yang saya lakukan saya paham. Dari data di atas terlihat bahwa pada siklus III aktivitas mau mencatat penjelasan peneliti meningkat menjadi $100 \%$.

Aktivitas siswa mau menulis hasil diskusi pada siklus I sangat sedikit. Siswa banyak yang malas untuk mencatat. Untuk itu pada pertemuan berikutnya peneliti menyarankan agar semua siswa walaupun sudah punya buku tapi usahakan untuk mencatat hal-hal yang penting. Menurut Marti (2014), siswa yang belajar dengan serius dan mencatat apa yang dibacakan oleh guru mempunyai persentase menjawab benar itu tinggi bila di bandingkan dengan siswa yang hanya memperhatikan dan tidak mencatat. Karena dengan mencatat kita akan mudah mengingat pelajaran yang sudah lewat. Pada siklus II aktivitas 
mencatat hasil diskusi mengalami peningkatan yang cukup baik dan siklus III aktivitas mencatat hasil diskusi mengalami kenaikan $100 \%$ ini berarti seluruh siswa yang hadir saat itu mencatat hasil diskusi semua. Siswa menyadari bahwa dengan mencatat akan memudahkan untuk mengingat bahkan untuk melihat lagi apa yang terlupakan akan menjadi gambaran yang mudah untuk dilihat dan menjadi contoh apabila ada soal atau latihan yang sama dengan yang dicatat.

\section{Keinginan siswa mau} mengeluarkan pendapat hanya sebagian saja. Dan juga siswa masih kelihatan malu-malu dan takut salah. Siswa yang memang sudah terbiasa berbicara mau menjawab dan mengemukakan pendapat yang mau mengeluarkan kata-kata dalam mengemukakan pendapatnya sehingga siswa yang lain yang keberaniannya hanya setengahsetengah merasa takut, takut salah dan tidak percaya diri. Dalam aktivitas ini siswa yang memang sudah terbiasalah yang berani mengemukakan pendapatnya dan mau bertanya dan yang sering berbicara yang berani mengemukakan pendapatnya di depan kelas.

Aktivitas siswa mau menjawab pertanyaan peneliti pada siklus I cukup baik, karena memang pada siklus I materinya cukup mudah dan siswa pun banyak yang memahami tentang materi tersebut. Dalam hal ini siswa sudah tahu tentang materi lingkaran dan unsurunsurnya. Apalagi pada pertemuan siklus I peneliti menjelaskan langsung dan sifatnya adalah teori saja. Setiap siswa punya buku sebagai media pembelajaran sehingga siswa dengan mudah memahaminya. Pada siklus II siswa mau menjawab pertanyaan peneliti mengalami penurunan ini disebabkan pada siklus II siswa mulai di ajak untuk menghitung berapa jumlah keliling dan bagaimana memperolehnya. Dalam hal ini siswa harus paham betul dalam menentukan rumus dan penggunaan nilai phi. Maka dari itu siswa yang lambat dan sulit berhitung maka siswa tersebut tidak bisa untuk menjawab. Pada siklus III aktivitas siswa mengalami kenaikan. Belajar dari siklus II peneliti memberi saran kepada siswa bahwa dalam menentukan rumus dan penggunaan nilai phi yang tepat sangat berpengaruh dalam kecepatan berhitung.

Aktivitas siswa menjawab pertanyaan teman termasuk ke dalam kategori rendah ini disebabkan karena siswa merasa malu pada temannya sendiri dan dianggap cari muka atau cari perhatian. Untuk siswa yang memang jarang menjawab memang lebih baik diam, tapi siswa yang memang suka mengikuti pelajaran tidak menjadikan penghalang baginya untuk menjawab pertanyaan siapa saja. Oleh sebab itu dari siklus I sampai siklus III aktivitas siswa mau menjawab pertanyaan temannya tidak mengalami kenaikan yang signifikan.Ini berarti menjawab pertanyaan baik dari guru maupun dari temannya sendiri bagi siswa yang punya kemampuan rendah atau Cuma setengah-setengah masih ada rasa takut dan malu, bahkan bisa jadi siswa tersebut memang tidak bisa berhitung atau tidak menemukan jawabannya. Biarpun keaktifan siswa pada poin ini rendah dan tidak mencapai kriteria yang di inginkan 
peneliti tapi pada setiap siklus selalu mengalami kenaikan.

Aktivitas siswa dalam kegiatan pembelajaran menggunakan media pelajaran pada setiap siklus mengalami peningkatan yang baik sekali. Pada siklus I siswa belajar yang mau menggunakan buku paket dalam belajar sangat sedikit. Bahkan ada yang sudah bawa tapi malah bukunya tak mau dikeluarkan dari dalam tasnya. Alasannya malas makin tambah bingung, karena pelajaran matematika itu sulit. Alasan yang diberikan siswa itu menunjukkan bahwa kurangnya kesadaran siswa untuk pintar. Oleh sebab itu pada siklus II peneliti memberikan penjelasan tentang arti pentingnya buku sebagai pedoman dalam belajar. Tanpa buku maka tak mudah bagi kita untuk jadi orang yang berhasil. Oleh sebagian siswa penjelasan peneliti menjadi masukan yang berharga, tapi bagi sebagian siswa yang lain masih belum. Pada siklus III semua siswa yang hadir sudah menggunakan buku paketnya sebagai media pelajaran. Sehingga pada siklus III ini pembelajaran dapat berlangsung dengan maksimal. Pada siklus III kegiatan belajar yang peneliti rasakan sangat semangat sekali.

\section{SIMPULAN DAN SARAN}

Berdasarkan hasil penelitian tindakan kelas yang telah dilakukan, dapat disimpulkan bahwa: 1) Perencanaan pembelajaran model NHT pada materi lingkaran di kelas VIII SMP Negeri 3 Kubu pada setiap siklus yang sudah peneliti persiapkan dan susun dapat terencana dengan baik.

2) Pelaksanaan pembelajaran model NHT pada materi lingkaran di kelas
VIII SMP Negeri 3 Kubu pada setiap siklus sudah baik sesuai dengan Rencana Pelaksanaan Pembelajaran (RPP) yang telah ditentukan. pembelajaran model NHT pada materi lingkaran di kelas VIII SMP Negeri 3 Kubu dapat meningkatkan aktivitas siswa, karena tingkat keaktifan siswa dalam pembelajaran tergolong tinggi dalam hal ini tingkat keaktifan siswa mau bertanya, mengemukakan pendapat, mau menjawab pertanyaan dan lain-lain sudah tercapai. 3) Dengan begitu pembelajaran melalui model NHT dalam upaya meningkatkan aktivitas siswa dalam proses pembelajaran matematika pada materi lingkaran kelas VIII semester 2 di SMP Negeri 3 dinyatakan berhasil.

\section{DAFTAR PUSTAKA}

Arikunto, Suharsimi, Suhardjono \& Supardi. (2006). Penelitian Tindakan Kelas. Jakarta: Bumi Aksara.

Ekasari, R. (2009). Eksperimen Pembelajaran Model Tutor Sebaya Untuk Mengatasi Kesulitan Belajar Matematika Ditinjau dari Kelengkapan Fasilitas Belajar Siswa Kelas VIII MTsN Walem. Skripsi. Surakarta: FKIP Universitas Muhammadiyah.

Isjoni. (2007). Cooperatif Learning: Mengembangkan Kemampuan Belajar Berkelompok. Bandung: Alfabeta.

Kussavita, R. (2007). Aplikasi Pakem (Pembelajaran Aktif Kreatif Efektif Menyenangkan) Model Rancangan Alat untuk 
14 Jurnal Pendidikan Matematika dan IPA Vol. 8. No. 1. Januari 2017: 1-14

Meningkatkan Prestasi

Belajar Biologi Siswa kelas

VII SMP Negeri I Ambarawa.

Skripsi. Surakarta:

Universitas Sebelas maret.

Marti, Syamswisna, dan Ruqiah Ganda Putri Panjaitan. (2014). Efektivitas pembelajaran kooperatif tipe NHT (Numbered Heads Together ) dengan media visual terhadap hasil belajar siswa pada materi organisasi kehidupan di kelas VII SMP REHOBOTH. Jurnal Pendidikan Matematika dan IPA, Vol.5, No.2, 21-27.

Mulyasa, E. (2010) Praktik Penelitian Tindakan Kelas. Bandung: Remaja Rosdakarya.
Muhammad, Nur. (2005). Model Pembelajaran Kooperatif Tipe NHT. Jakarta.

Silberman, Melvin. (2006). Active Learning: 101 Cara Belajar Siswa Aktif. Bandung: Nuansa.

Spencer, Kagan. (1993). Model Pembelajaran NHT.

Trianto. (2007). Model-model Pembelajaran Inovatif Berorientasi Konstruktivistik. Jakarta; Prestasi Pustaka Publisher.

Uno, B., Hamzah. (2007). Model Pembelajaran Menciptakan Proses Belajar Mengajar Yang Kreatif dan Efektif Jakarta: Bumi Aksara. 